\title{
Article \\ Solar Energy as a Form Giver for Future Cities
}

\author{
Alessandra Curreli, Glòria Serra-Coch, Antonio Isalgue, Isabel Crespo and Helena Coch * \\ Architecture \& Energy, School of Architecture of Barcelona, UPC. Av. Diagonal, 649, 7th Floor, 08028 Barcelona, \\ Spain; alessandracurreli@gmail.com (A.C.); gloriaserracoch@gmail.com (G.S.-C.); \\ antonio.isalgue@upc.edu (A.I.); isabel.crespo@upc.edu (I.C.) \\ * Correspondence: helena.coch@upc.edu; Tel.: +34-93-4010868
}

Academic Editor: Jukka Heinonen

Received: 1 May 2016; Accepted: 7 July 2016; Published: 14 July 2016

\begin{abstract}
Energy is considered as a main influence on urban configurations. However, there is a difficulty on translating the city models based on theoretical renewable energy concepts into practical applications. This study considers the possibility of understanding this future model as a transformation of the existing urban centres. With this objective, a methodology to intervene in existing cities based on the study of solar access is developed. Therefore, an analysis of solar potential in relation with urban morphology is carried on through a simulation software in l'Eixample, a neighbourhood of Barcelona. The distribution of the sun factor in the different areas of the building blocks envelope displays possible morphological modifications that would facilitate solar energy collection. Consequently, the analytical method presented could be applied to regulate urban interventions with the aim of obtaining more solar energy based cities.
\end{abstract}

Keywords: urban morphology; solar access; renewable energies; reuse; cities; energy

\section{Introduction}

Energy and energetic fluxes are considered as a main driver of urban configuration transformations [1]. It is possible to identify a connection between social and physical organization of urban settlements and their supply systems, transformation means and available resources [2].

The purpose of this article is to explore the relation between energy and urban centres and exploit its characteristics to determine a strategy to intervene in existing settlements. This methodology will address the urban scale with the aim of adapting cities to the must be energy sources of humanity development: renewable energies.

From the Neolithic to pre-industrial era, sun, wind, blood-force and biomass were used to produce thermal and mechanical energy [3]. This energetic sources restricted urban growth by creating a close physical and temporal connection between production and consumption. The intrinsic characteristics of energetic sources, the supply systems present at the time and the storage difficulties gave as a result a balance between demand and supply and the reduction of cities impact on their natural surroundings [4].

With the introduction of coal as an energy resource during the Industrial era, the connection between production and consumption was firstly broken [3]. On the one hand, this energetic resource maximized the possible immediate production while, with the invention of the steam engine and the introduction of the railway network, it disconnected the distance relation between the extraction and the production [5]. Industries acted as a population pole of attraction, source of a rural exodus that brought congestion and insalubrious living conditions in cities [6,7].

The introduction of electricity as a transportation system brought a complete disengagement between energetic resources and urban centres locations. The capillarity of energy distribution and the subsequence expansion of transportation flexibility allowed for new urban structures, morphologies 
and typologies. Urban vertical growth was a result of the elevator invention combined with rapid transit systems [8].

The process of disassociation between settlements expansion and their energetic sources made a new last step forward during the second Industrial Revolution [1] with the use of oil as a main energetic resource. Fossil combustibles created the illusion of unlimited capacity of urban expansion by delaying the noticeable effects and, therefore, cities were able of freely growing without being aware of the long term consequences.

Cities began a process of transformation related with horizontal and extensive urban growth, bringing with it the new concept of "urban sprawl" [9]. Car use and roads networks brought low density structures with a lack of public space and social centres $[10,11]$. Nonetheless, this urban morphology not only influenced the city structure from a social scope but also generated important consequences for the environment [12].

With the oil crisis of 1973 the effects of this disengagement became suddenly visible and public concern focused on the current problematic. As a result, the definition of sustainability was first presented in 1984 [13], a concept repeatedly used since then. However, although the path to follow seemed explicit, the concept and its practical applications progressively lost clarity while gaining a strong media role and losing solid scientific background to support it.

Nevertheless, the relation between environmental problematic and urban centres was evident and several schools of thought started addressing the issue [14-16]. The final objective was to obtain complex, socially equitable and energy efficient settlements; capable of offering good living conditions to citizens and characterized by a good balance between demand and production.

Consequently, the need to achieve a model of urbanism that addresses these new issues has been widely discussed. Recovering the balance between production and consumption and reconnecting urban expansion with its energetic possibilities seems a must. The introduction of renewable energies is the clearest path to achieve these objectives and giving the sun the main role as primary energetic source [17] seems the most sensible strategy to be able to restore the balance of the pre-Industrial era.

However, when translating the idea of developing renewable energies based settlements into practice, most cases find themselves faced with a contradiction between the theoretical model and the existing possibilities [15]. Generally, the outcomes of these attempts are newly made urban centres that become more a mere addition of low-emission buildings than an organism that works as whole.

Moreover, these renewable energies based neighbourhoods tend to be presented as new constructions that expand in the terrain, colonizing the fertile soil that can usually be found around historical urban centres. Although addressing cities enlargement with energetic and environmental issues as main objectives, the strategy of growing into the occupation of new fertile terrain involves clear negative environmental consequences by itself.

On the other hand, many previous researches have been developed about the relationship between the configuration and the solar potential of an urban fabric. Nevertheless, most of them focused on generic archetypal urban forms [18-21] without fully considering the morphological specificities that characterize the existing urban environments. Some current studies have proved that morphological fabric features might have an important role in the solar potential of an urban tissue [22,23], as well as other comfort factors, like the possibilities for ventilation [24].

For all these reasons, this article contemplates the need of creating a methodology to translate theoretical concepts regarding energy use in general, and solar use in particular, in urban centres into practical applications. This methodology will be based on the creation of a set of solar indicators that will be the basis for operative tools to intervene in the existing. To be able to achieve more consistent results, the strategies will be developed at the level of urban morphology instead of only focusing on the building as a single and unrelated unit or considering the urban fabric as an archetypal model, such as other studies, like the urban canyon model [25]. Finally, it is stressed the importance on developing strategies to intervene in the existing built environment and transforming it into the renewable energy based urban centres needed, instead of promoting alienated new models. 
Accordingly, this study aims to outline a methodology that promotes practical and concrete actions to improve existing urban settlements by analysing their solar potential in relation with urban morphology. This methodology has the objective of indicating architectural modifications to implement in an urban tissue to be able to take advantage of the solar potential. The design and construction of systems to exploit this solar energy — such as solar panels, photovoltaic cells, windows, trombe-walls ... etc.-would be a posterior step that is not addressed in this article as it has already been covered in other scientific publications [26]. In order to assess the possible exploitation of the solar potential, the incoming direct radiation will be studied considering its distribution on the different parts of the block.

\section{Results}

\subsection{Case Study}

The Eixample district in the city of Barcelona is considered a representative case study to be analysed. It is the result of a rigorous and innovative urban planning process developed during the 19th century by the civil engineer Ildefons Cerdà.

The project is based on an exhaustive topographic plan of the area around the existing Barcelona [27] and a detailed empirical report of its critical unsanitary conditions at the time of industrialization [28], providing also a specific analysis of the city climate [29]. Its success is a consequence of a very thorough analysis and a solid theoretical basis [30].

Like most other extension plans of the time, its development is based on a regular grid, associated with the new objective of rationalizing the planning process, supported as well by the introduction of methodological attitude [31] based on the idea, the territory, the regulations and the design as fundamental phases [32]. An exceptional characteristic of this plan is its size, covering an area ten times the extension of the existing city. With the aim of ensuring equal healthy sanitation to all the inhabitants, Cerdà designed the basic unit as a square block $(113 \times 113 \mathrm{~m})$ with a $45^{\circ}$ North orientation, in order to provide a "democratic" sunlight distribution to the different façades [27].

Moreover, the circulation of the people and the goods were given a foreseeing importance. The presence of new forms of mobility (the railway and, some decades later, the car) determined the definition of a base layout with 20-metre-wide streets, where the dimensions reserved for vehicles and pedestrian were distributed in two equivalent halves. The chamfered corners of the blocks would facilitate the change of direction of the different circulation flows in the crossings and main metropolitan axes with dimensions ranging 50-100 m were superposed to the orthogonal grid [30].

The final objective of the project was to propose a new functional and hygienic urban model in order to regulate the expansion of the existing city. Although the plan (Figure 1a) was extensively modified during its construction, the urban principles elaborated by Cerdà are still valid, with a clear aim to ensure the comfort and quality of city life [33].

For this reason, it is interesting to analyse the effective performance of the current Eixample, (Figure 1b) considering the environmental and energetic needs of the contemporary city. More specifically, the attention is focused on the solar radiation access and to the possibilities of exploitation of the energy collected by the buildings. 


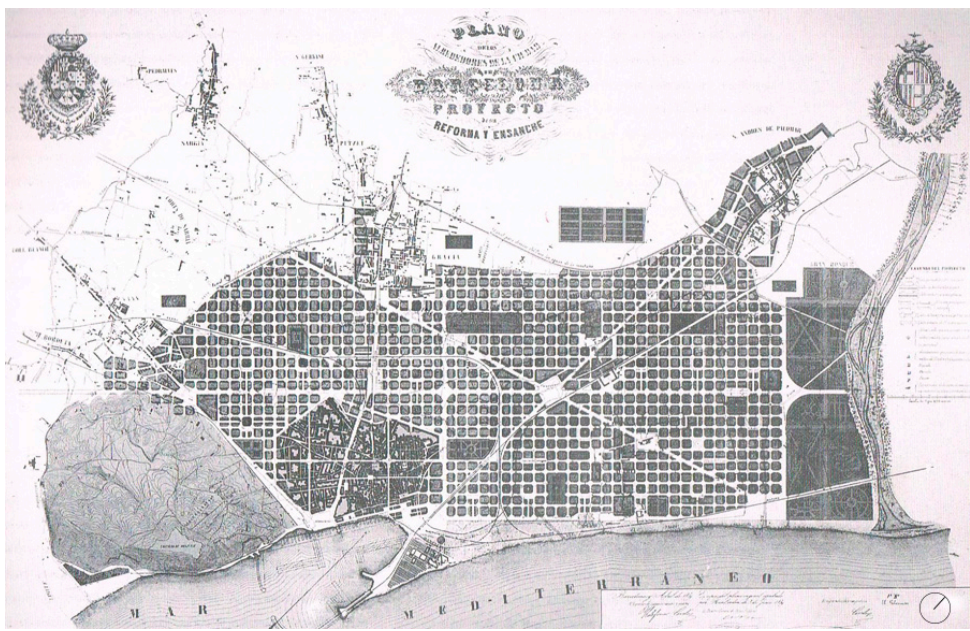

(a)

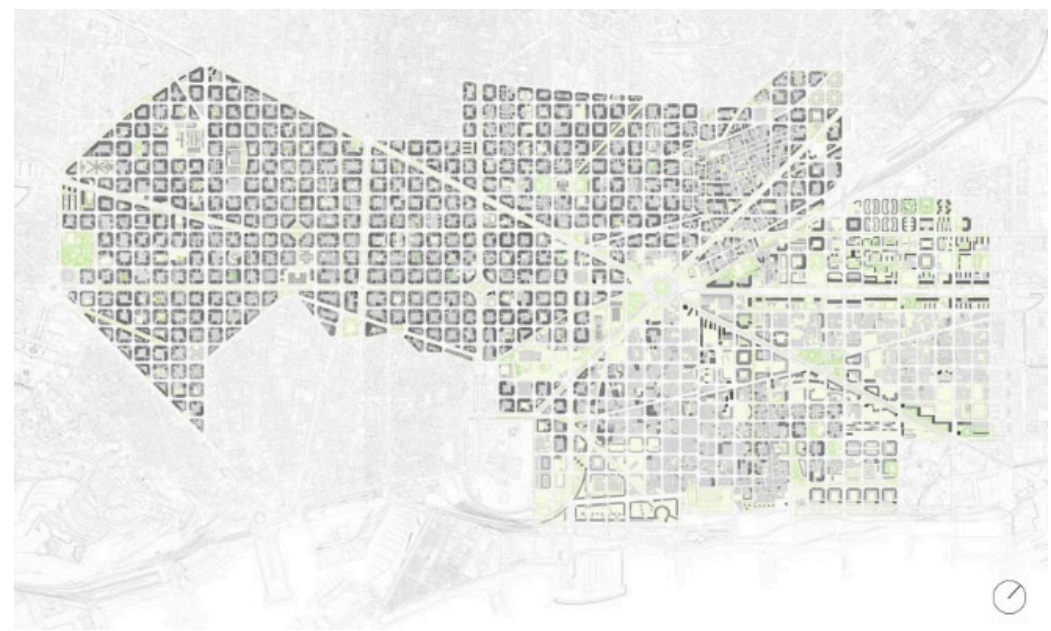

(b)

Figure 1. (a) Idelfons Cerdà Eixample plan 1859. Imposed by royal decree the 31 March 1860. Arxiu Històric de la Ciutat de Barcelona; (b) Current Eixample. Author: Centre de Cultura Contemporania de Barcelona (CCCB).

\subsection{Distribution of the Sun Factor (F)}

The graphics in the Figure 2 show the global distribution of the Sun Factor- $F\left(\mathrm{kWh} / \mathrm{m}^{2}\right.$ per season) in the Eixample block's envelope, in winter (Figure 2a) and in summer (Figure 2b).

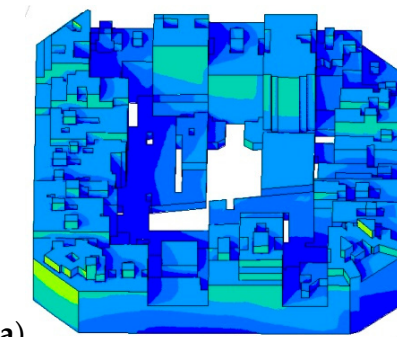

(a)

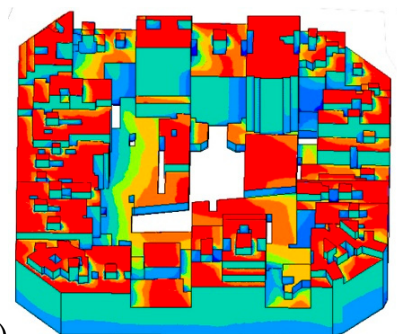

(b)

$\begin{array}{lllllllll}0 & 70 & 140 & 210 & 280 & 350 & 420 & 490 & 560\end{array}$

Figure 2. Global distribution of the Sun Factor $-F\left(\mathrm{kWh} / \mathrm{m}^{2}\right)$ in the Eixample block's envelope, in winter (a) and in summer (b). 
It is noticed that the solar flux is generally higher and more uniform on the horizontal surfaces with respect to the vertical ones, due to the major influence of the surrounding blocks on the façades and to the orientation of the urban grid. Effectively, on the external fronts, the losses in solar gains due to the shadows cast by the neighbouring buildings are about $28 \%$ in winter and $13 \%$ in summer. The influence of obstructions $(I)$ is almost null on the roofs, where $(I)=0.2 \%$, since the height of the blocks in the selected sample is quite homogeneous. In this sense, it can be deduced that the morphological characteristics of the urban plot only affects the vertical external surfaces of the block.

By analysing the outcomes of the solar simulation in terms of Sun Factor $\left(\mathrm{kWh} / \mathrm{m}^{2}\right)$, it is observed that the different portions of the block show a variable performance (see the bar graphs in Figure 3). As it was expected, the maximum values of Sun Factor $(F)$ are located on the roofs (124 and $428 \mathrm{kWh} / \mathrm{m}^{2}$ in winter and summer, respectively) and on the internal courtyard (77 and $368 \mathrm{kWh} / \mathrm{m}^{2}$ in winter and summer, respectively).

The outer fronts of the block provide a solar potential of 85 and $158 \mathrm{kWh} / \mathrm{m}^{2}$ in the two periods of the year that have been simulated. In the winter season, the external vertical solar potential is slightly higher than that of the patio, due to the steep inclination of the sun's rays $\left(23^{\circ}\right.$ at $12: 00 \mathrm{~h}$ at the winter solstice).

The values of the Sun Factor $(F)$ on the inner façades $\left(71 \mathrm{kWh} / \mathrm{m}^{2}\right.$ in winter and $123 \mathrm{kWh} / \mathrm{m}^{2}$ in summer) slightly decrease compared with those detected on the outer vertical envelope. In fact, in the present case, although the distance between opposite fronts is about $55-60 \mathrm{~m}$ and the ratio between the height of the buildings and the wide dimension of the street $\mathrm{H} / \mathrm{W}=0.25$, the shadows projected by the lateral sides of the block have to be taken into account. This means that the interior part of the block has a more complex solar behaviour compared with the simplified model of the urban canyon, normally associated to the external façades [25].

\section{SUN FACTOR $\left(\mathrm{kWh} / \mathrm{m}^{2}\right)$}

Winter season

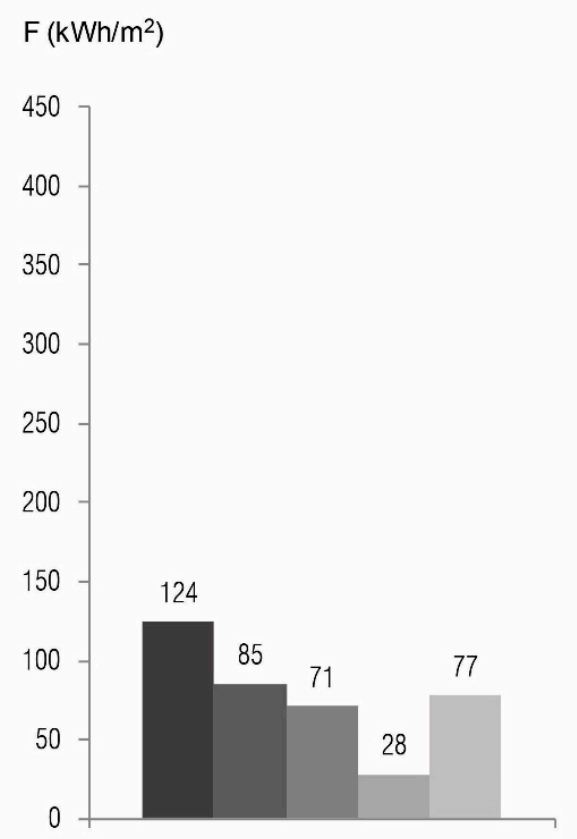

\section{Summer season}

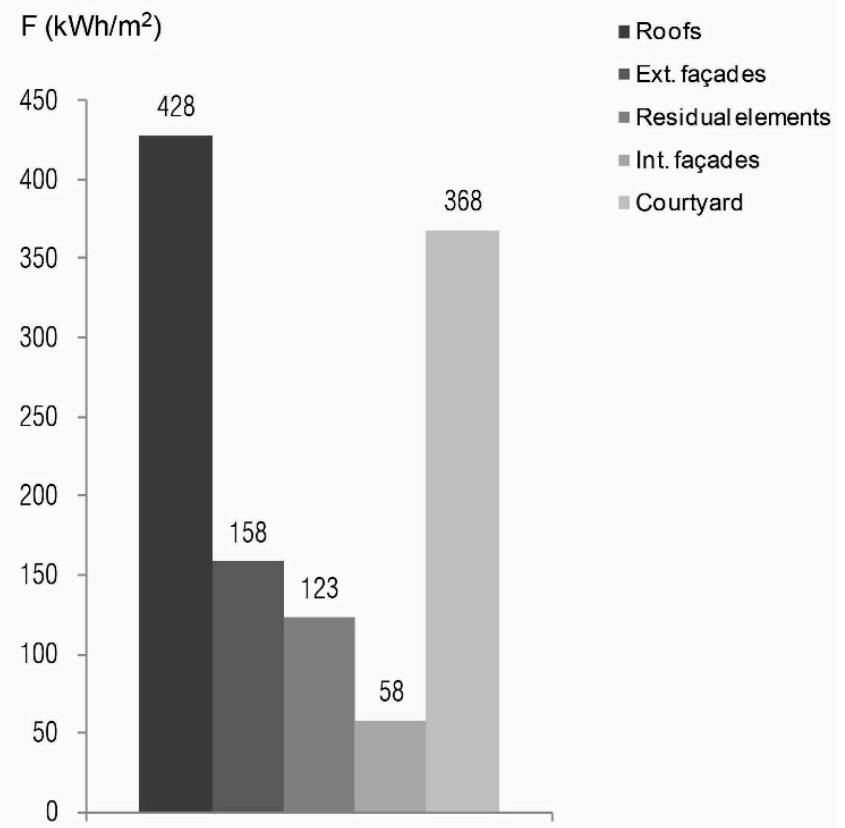

Figure 3. Distribution of Sun Factor $F_{R}\left(\mathrm{kWh} / \mathrm{m}^{2}\right)$ in the different envelope components during the winter and summer season.

Finally, the lowest values of solar potential are registered on the "residual elements" of the block, such as wells, stairwells, small projections and the folders of the façades and so on, where the solar 
energy collection is not directly exploitable. In this case, the Sun Factor (F) is $28 \mathrm{kWh} / \mathrm{m}^{2}$ during the winter season and $58 \mathrm{kWh} / \mathrm{m}^{2}$ during the summer season. The overall area of the secondary elements is about $22.000 \mathrm{~m}^{2}$ (almost a half part of the whole envelope) which represents a very important potential surface for solar collection. Nevertheless, it is noticed that the mutual shadows cast by these elements drastically reduce the solar access on them.

\subsection{Distribution of the Potential Solar Gains (G)}

In terms of Potential Solar Gains-G (kWh), the performance of the Eixample block displays a trend that is very similar to the one described in the previous paragraphs with regard to the Sun Factor-F. However, the analysis of the solar indicator $G$ highlights other important issues.

The graphs in Figure 4 display the percentage of solar energy accumulated by the different components of the block's envelope. The highest contributions proceed from the roofs, which collect a percentage of $33 \%$ and of $43 \%$ of the total amount of $G$, during the winter and during the summer, respectively.

The percentage of potential solar gains provided by the external façades is also quite relevant, varying between $24 \%$ in winter and $17 \%$ in summer. The possibilities for solar access are basically affected by the configuration of the urban fabric and, more specifically, by the proportions of the urban canyon, $\mathrm{H} / \mathrm{W}$.

The contribution of the inner façades in terms of solar collection is about $14 \%$ in winter and $9 \%$ in summer. These values are considerably lower than those registered in the previous case, due to the influence of the transversal facades. In other words, the solar performance depends on the interior morphology of the courtyard but it is not affected by the external obstructions.

It is quite interesting to observe that the "residual elements" cover between $16 \%$ (in the warm season) and $21 \%$ (in the cold season) of the global solar gains. These contributions are almost equivalent to those of the outer façades. This means that approximately one fifth of the solar energy collected by the block is not exploitable at all for a passive use or an active use, such as photovoltaic or thermal panels.

Remarkably, the lowest percentages are detected in the central patio, where the energy collected is about $8 \%$ and $15 \%$ of the global solar gains, in winter and summer, respectively. In fact, although the Sun Factor $\left(\mathrm{kWh} / \mathrm{m}^{2}\right)$ reaches its maximum values on the horizontal components of the block (the roofs and the courtyard), the surface of exposure of the latter (about $3.000 \mathrm{~m}^{2}$ ) is definitely smaller than those of the other elements.

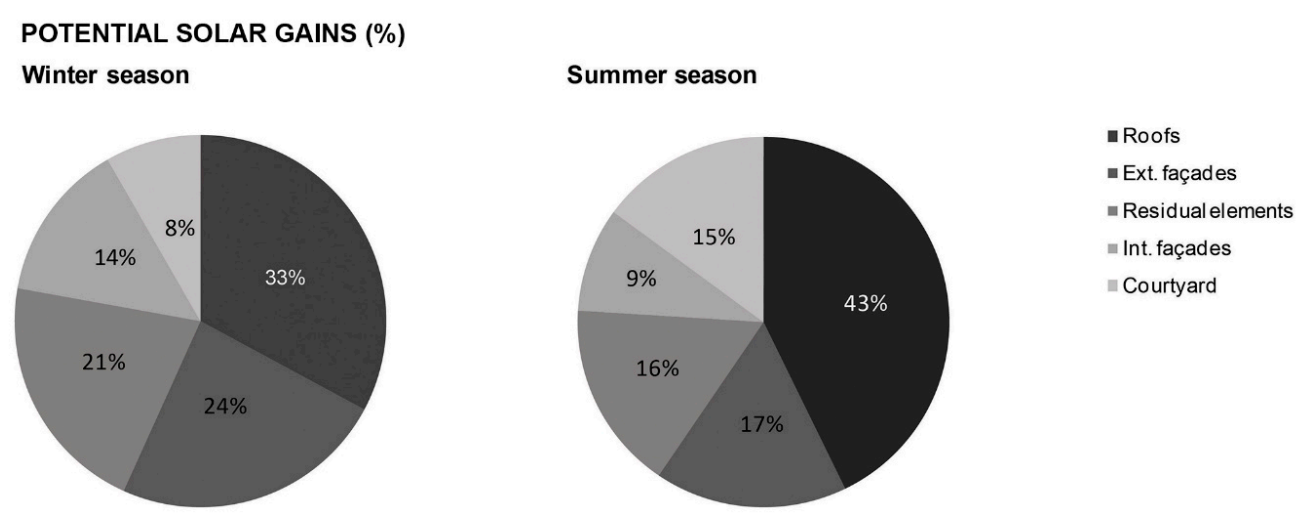

Figure 4. Percentage distribution of solar gains potential $G(\mathrm{kWh})$ in the different envelope components during the winter season and summer season. 


\section{Discussion}

In the previous paragraph, the outcomes of the solar simulation have been studied and compared in quantitative terms. Nevertheless, it is interesting to analyse and discuss the same results from a qualitative point of view, in order to assess which are the actual viable possibilities to improve the solar efficiency of the Eixample urban fabric.

The maximum solar access, both in terms of Sun Factor $(F)$ and Potential Solar Gains $(G)$, has been detected on the roofs of the buildings. However, it should be taken into account that the complex and articulated morphological structure of this part of the envelope could make the installation of photovoltaic or thermal panels difficult and, therefore, restrain the opportunities for an active use of the solar energy. Consequently, a possible morphological urban intervention could be based on the levelling of horizontal surfaces in roofs, with the objective of facilitating the installation of active solar energy collecting elements.

The configuration of the central patio, instead, offers concrete opportunities to be transformed into a common public space for the neighbours of the block, where the social use of the solar energy could be exploited. In the last decades, the City of Barcelona implemented many successful interventions aimed at recovering the Eixample inner central courtyards; which have shown that the possibility to improve the solar efficiency in these parts of the block is viable and concrete.

Concerning the vertical solar potential, it is important to highlight that the $45^{\circ}$ rotation of the streets grid with respect to the North allows a homogeneous and equitable distribution of the solar gains on the envelope in terms of thermal energy and natural lighting [34]. Consequently, during the winter, this orientation provides two symmetrical possible "collector" sides facing South-East and South-West. During the summer, when protection from the solar radiation is normally required in a Mediterranean climate, it allows to have two sheltered façades towards North-East and North-West. The Eixample typology of two-façade sequenced dwelling, enjoying two orientations, benefits greatly from this urban structure. Therefore, the preservation of this typology should be enhanced to avoid losing its urban solar advantages.

Furthermore, the presence of the courtyard and the dimensional proportions of the Eixample urban plot increase the overall surface of exposure, not only in the external façades, but also in the inner sides of the block, incrementing the possibilities for a passive use of the solar energy.

The solar analysis demonstrated that the existing Eixample urban fabric offers different potential opportunities to enhance the employment of the solar radiation. Consequently, a structured analysis of the existing urban fabric allows to detect the areas of solar potential and their possible improvements.

The positive solar characteristics of the Eixample district are closely related with its planning by I. Cerdà that, according to functional and hygienist design criteria, aimed at ensuring healthy and high-quality life conditions to all its inhabitants. Although the Eixample followed a process of intense building densification, its main morphological features are still recognizable and effective, both at the scale of the block and at the scale of the urban fabric.

\section{Materials and Methods}

The solar analysis has been carried out by means of the simulation software Heliodon 2, a digital tool which computes the energy collected by the buildings' envelope during a determined period of time (day, month, season, year) and also reports the average values, if required [35]. In the present study, only the direct radiation has been taken into account. Possible effects of climate change are not considered in this case.

Within the Eixample urban fabric, a homogeneous sample composed by nine blocks laid out in a $3 \times 3$ layout has been selected (Figure 5). The model has been developed with the Computer Aided Design Software Autocad 2010 in three dimensions and real scale. The $3 \mathrm{~d}$ sample has been modelled by following the principles defined by the Open Geospatial Consortium for the LoD2 scale, which considers a morphological detail scale with deviations smaller than $2 \mathrm{~m}$ compared with reality. This level of detail is considered appropriate based on several factors: Firstly, the availability of 
geometrical information on the analysed sector. Secondly, the technical potential of the used software, Heliodon and Autocad. Finally, and more important, the expected deviation from results that this simplification could involve [2] (Figure 6).

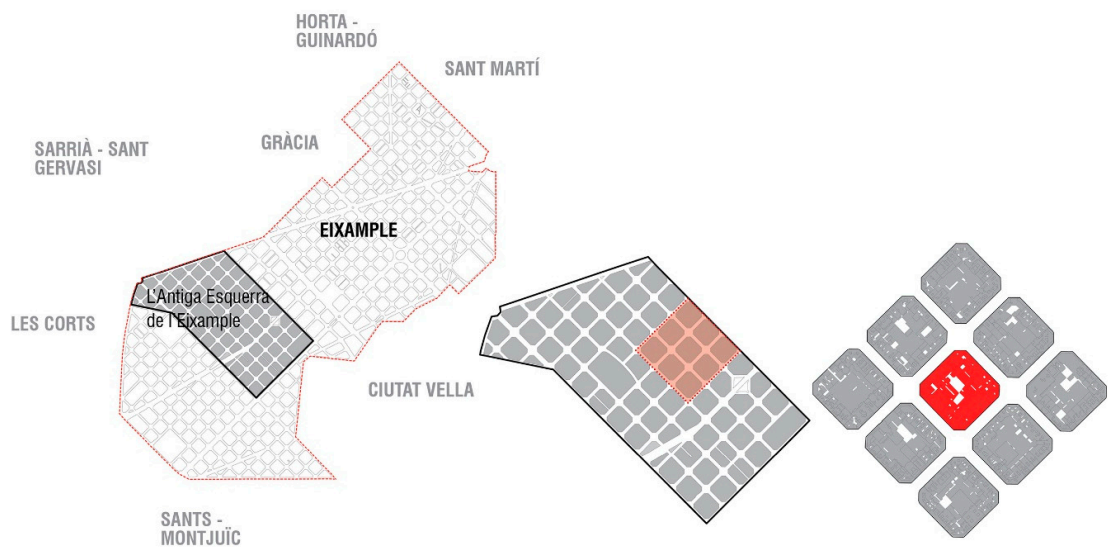

Figure 5. Location of the studied sample and identification of the central unit in relation with the influencing surrounding.
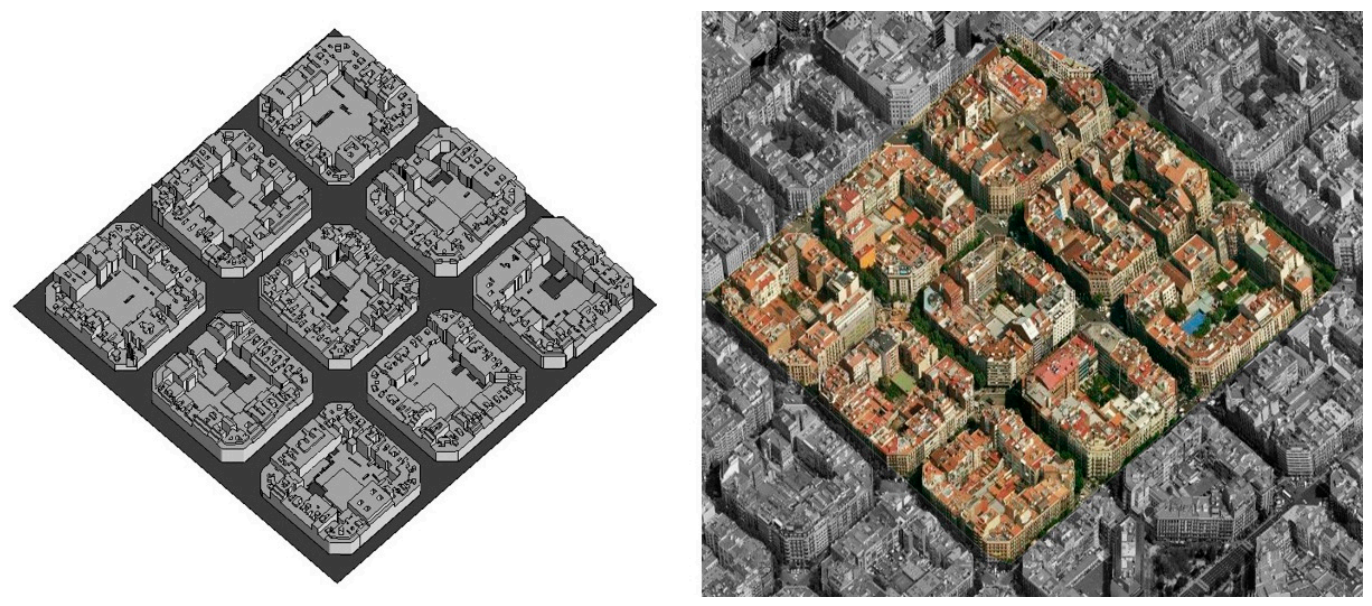

Figure 6. 3D virtual morphological model of the homogeneous sample composed by 9 blocks of the Eixample urban fabric compared with an aerial photograph.

The virtual model was built using the land register cartographic base, available for digital download at the website of the Barcelona City Council. A supervising field work was carried on, to validate the obtained geometry and the accuracy of the used base. The reduced extension of the sample and the regular topography of the terrain allowed considering the territory as completely flat. The influence of vegetation and urban furniture was disregarded, as the focus of the study was centred on the built environment [2].

The solar gains have been calculated for the central block in both summer (from 21 June to 20 September) and winter (from 21 December to 20 March) season, considering the presence of the surroundings blocks which act as obstructions.

Three main solar indicators are defined in order to assess the solar performance of the Eixample urban fabric, which are:

- The Potential Solar Gains $-G(\mathrm{kWh})$, which represent the global amount of energy cumulated by an exposed surface. 
- The Sun Factor $-F\left(\mathrm{kWh} / \mathrm{m}^{2}\right)$, which expresses the average solar flux per surface unit area.

- The Influence of Obstructions-I (\%), which evaluates the losses in potential solar gains due to the shadows cast by the neighbouring blocks.

It is considered that the solar potential of an urban fabric does not simply correspond to the quantity of the potential solar gains, but it depends on the actual possibilities to exploit the energy collected for an active and/or a passive use.

Therefore, in order to assess the extent by which the Eixample block could really exploit regarding its solar potential, it is necessary to study the distribution of the incoming direct radiation on the different parts of the block, which have been classified in five main categories: the roofs, the central courtyard ground, the external façades (facing the street), the internal façades (facing the internal courtyard) and the "residual surfaces". The last group includes all the irregular elements of the block's envelope where the employment of the solar energy collected is not considered feasible at all, such as the small patios, the stairwells, the projections and the folders of the façades etc.

\section{Conclusions}

This study shows the possibilities of applying a methodology into a real case study to translate theoretical concepts regarding energy use in urban centres into architectural practical applications. This methodology has been based on a structured analysis of the existing, extracting general functional parameters of the urban tissue and obtaining possible urban morphological modifications based on the existing characteristics and possibilities. Therefore, the new possible city model we present based on the use of renewable energies is a reconversion of existing tissues through operative tools based on methodological processes of analysis and strategy driven interventions. The analysis in a morphological urban scale has been proved essential to extract the main characteristics of the case study and develop a set of intervention strategies. This strategy has shown the importance of addressing current energy problems from an urban scale instead of only focusing on building's optimization. Strategies developed on a greater scale, with a convenient analysis and methodology to support them, can achieve more decisive results than disconnected interventions. On the other hand, this study also displays the importance of addressing the urban scale not only from a typological point of view but also from a morphological perspective, to be able to extract information from typological deviation that might become crucial to fully analyse the tissue from an energetic point of view. Nevertheless, further steps after the urban analysis are also advisable to exploit the possibilities from a building scale, including the detailed collecting systems implemented for different uses (heating, electricity, lighting ...).

Although this article develops a methodology based on the study of solar radiation due to its important role in the field of renewable energies, the same structure could be applied to other energy issues. Therefore, a set of strategies regarding energetic interventions in the existing could be built to form a more precise set of operative tools to intervene in existing urban tissues.

Moreover, it should also be considered that by addressing urban morphology through the energetic point of view other structural and social changes will also be triggered in urban centres. Although the main present concern is related with environmental issues, it is important to take into account other consequences of urban morphology transformation. Therefore, further investigations should focus on developing these side effects to achieve a complete picture of the subject.

Acknowledgments: This work has been supported by the Spanish Ministry of Economy under project code: BIA2013-45597.

Author Contributions: The five authors contributed equally to the present paper. Curreli, A. conceived and designed the main part of the research work during the thesis development. Coch, $\mathrm{H}$. supervised the thesis. All authors wrote, reviewed and commented on the manuscript. All authors have read and approved the final manuscript. 
Conflicts of Interest: The authors declare no conflict of interest. The founding sponsors had no role in the design of the study; in the collection, analyses, or interpretation of data; in the writing of the manuscript, and in the decision to publish the results.

\section{References}

1. Droege, P. La Città Rinnovabile; Guida Completa ad una Rivoluzione Urbana; Edizioni Ambiente: Milano, Italy, 2008. (In Italian)

2. Curreli, A. El Acceso Solar a la Escala del Tejido Urbano. Ph.D. Thesis, Universitat Politècnica de Catalunya, Barcelona, Spain, 25 January 2016.

3. De Pascali, P. Città ed Energia. La Valenza Energetica dell'Organizzazione Insediativa; Franco Angeli Edizioni: Milano, Italy, 2008.

4. Butera, F.M. Energia e Tecnologia fra Uomo e Ambiente, 1st ed.; Città Studis.s.c.r.l.: Milano, Italy, 1992.

5. Butera, F.M. Della Caverna a la Casa Ecologica. Storia del Comfort e dell'Energia; Edizioni Ambiente: Milano, Italy, 2004.

6. Benevolo, L. Storia dell'Architettura Moderna, 18th ed.; Laterza: Roma, Italy, 1960.

7. Mumford, L. La Cittá Nella Storia; Edizioni di Comunità: Milano, Italy, 1964.

8. Banham, R. The Architecture of the Well-Tempered Environment, 2nd ed.; University of Chicago Press: Chicago, IL, USA; The Architectural Press Ltd.: London, UK, 1984.

9. Ewing, R. Characteristics, Causes and Effects of Sprawl: A Literature Review. In Urban EcologyAn International Perspective on the Interaction Between Humans and Nature, 1st ed.; Marzluff, J., Shulenberger, E., Endlicher, W., Alberti, M., Bradley, G., Ryan, C., ZumBrunnen, C., Simon, U., Eds.; Springer USA: New York, NY, USA, 2008.

10. Banham, R. Los Angeles: The Architecture of Four Ecologies; Allen Lane the Penguin Press: London, UK, 1971.

11. Mumford, L. New York et l'Urbanisme; Editions Seghers: Paris, France, 1965.

12. Raydan, D.; Steeners, K. Environmental urban design. In Environmental Design of Urban Buildings: An Integrated Approach; Santamouris, M., Ed.; Routledge: New York, NY, USA, 2006; pp. 1-35.

13. World Commission on Environment and Development. Our Common Future; Oxford University: Oxford, UK, 1987.

14. Beatley, T. Green Urbanism: Learning from European Cities; Island Press: Washington, DC, USA, 2000.

15. Hagan, S. Ecological Urbanism: The Nature of the City; Routledge: London, UK; New York, NY, USA, 2015.

16. Lehmann, S. Green Urbanism: Formulating a series of holistic principles. Sapiens 2010, 3. Available online: https:/ / sapiens.revues.org/1057 (accessed on 25 April 2016).

17. Winter, C.J. Solar cities. Renew. Energy 1994, 4, 15-26. [CrossRef]

18. Gupta, V. Thermal efficiency of building clusters: An index for non air-conditioned buildings in hot climates. Energy Urban Built Form 1987, 2, 133-145.

19. Ratti, C.; Raydan, D.; Steemers, K. Building form and environmental performance: Archetypes, analysis and an arid climate. Energy Build. 2003, 35, 49-59. [CrossRef]

20. Sattrup, P.A.; Strømann-Andersen, J. Building typologies in northern European cities: Daylight, solar access and building energy use. J. Archit. Plan. Res. 2013, 30, 56-76.

21. Compagnon, R. Solar and daylight availability in the urban fabric. Energy Build. 2004, 36, 321-328. [CrossRef]

22. Rasheed, A.; Robinson, D.; Narayanan, C.; Lakehal, D. On the effects of complex urban geometries on mesoscale modelling. In Proceedings of the 7th International Conference on Urban Climate, Yokohama, Japan, 29 June-3 July 2009.

23. Curreli, A.; Coch, H. 3-D geometrical modelling and solar radiation at urban scale: Morphological or typological mock-ups? In Proceedings of the CISBAT2013 International Conference: Cleantech for Smart Cities and Buildings form Nano to Urban Scale, Lausanne, Switzerland, 4-6 September 2013; pp. 1029-1034.

24. Jurelionis, A.; Bouris, D.G. Impact of Urban Morphology on Infiltration-Induced Building Energy Consumption. Energies 2016, 9, 177. [CrossRef]

25. Rubio-Bellido, C.; Jesús, A.P.-A.; Sánchez-Montañés, B. A Simplified Simulation Model for Predicting Radiative Transfer in Long Street Canyons under High Solar Radiation Conditions. Energies 2015, 8, 13540-13558. [CrossRef]

26. Coch, H.; Pardal, C.; Pagès-Ramon, A.; Isalgué, A.; Crespo, I. Better than optimum: Integrated: The integration of renewable energy in architecture as an optimization factor. Renew. Energy Serv. Mank. 2015, 2, 569-579. 
27. Permanyer, L. L'eixample, 150 Anys d'Història; Viena Edicions: Barcelona, Spain, 2008.

28. Cerdà, I. 1867-Teoría general de la Urbanización y Aplicación de sus Principios y Doctrinas a la Reforma y Ensanche de BarcelonaImprenta Española: Madrid, Spain, 1867; Edition facsímile; Instituto de Estudios Fiscales: Madrid, Spain, 1968-1971.

29. De Manuel, S.-M. Deu Lliçons Sobre Barcelona; Laboratori d'Urbanisme de Barcelona: Barcelona, Spain, 2008.

30. Busquets, J. Cerdà i la Barcelona del Futur; Centre de Cultura Contemporànea de Barcelona: Barcelona, Spain, 2009.

31. Solà Morales, M. Els Eixamples. Treballs sobre Cerdà i el seu Eixample a Barcelona; Laboratori d'Urbanisme de Barcelona: Barcelona, Spain, 1992.

32. Solà Morales, M. Cerdà/ Ensanche; Ediciones UPC: Barcelona, Spain, 2010.

33. Busquets, J. Projecte d'eixample vs. Eixample actual. In Treballs Sobre Cerdà $i$ el seu Eixample a Barcelona, 1st Ed.; Busquets, J., Corominas, M., Eizaguirre, X., Sabaté, J., Eds.; Laboratori d’Urbanisme de Barcelona: Barcelona, Spain, 1992.

34. Curreli, A.; Coch, H. Urban Layout and Façade Solar Potential: A case study in the Mediterranean Region. ACE 2013, 21, 116-132.

35. Beckers, B.; Rodríguez, D. Helping architects to design their personal daylight. WSEAS Trans. Environ. Dev. $2009,7,467-477$.

(C) 2016 by the authors; licensee MDPI, Basel, Switzerland. This article is an open access article distributed under the terms and conditions of the Creative Commons Attribution (CC-BY) license (http:/ / creativecommons.org/licenses/by/4.0/). 